\title{
Photopolymerization without Light - Polymerization of Acrylates Using Oxalate Esters and Hydrogen Peroxide
}

Andrei A. Ermoshkin, Douglas C. Neckers*

Centerfor Photochemical Sciences, Bowling Green State University, Bowling Green, $\mathrm{OH}$ 43403

Andrei V. Fedorov*

Wright Photoscience Laboratory, Department of Chemistry, Bowling Green State

University, Bowling Green, OH 43403

\section{Supporting Information}

\section{Synthesis of Model Peroxides}

The syntheses were done according to the procedure of Lahti et. al. [1] with some modifications. Commercially available $90 \%$ water solution of tert-butyl hydroperoxide (10 ml) was dissolved in $50 \mathrm{ml}$ of pentane and dried over $\mathrm{Na}_{2} \mathrm{SO}_{4}$. The solution was filtered and pentane was removed at reduced pressure at $0^{\circ} \mathrm{C}$. During all next steps precautions were taken to keep the reaction mixtures and products at $0^{\circ} \mathrm{C}$ and at the absence of a daylight at all time - syntheses and work-up were carried out at illumination by reduced intensity tungsten lamp. Authors of [1] also do not recommend to carry these reactions out on significantly larger scales.

tert-Butylperoxyoxalyl Chloride solution.

The solution of oxalyl chloride $(13.42 \mathrm{~g}, 105.7 \mathrm{mmol})$ in $35 \mathrm{ml}$ of pentane was cooled to $0^{\circ} \mathrm{C}$ under atmosphere of dry argon. A solution of previously dried tert-butyl hydroperoxide $(2.3 \mathrm{~g}, 25.6 \mathrm{mmol})$ in $40 \mathrm{ml}$ of pentane was added dropwise over $30 \mathrm{~min}$ via syringe and the reaction mixture was stirred at $0^{\circ} \mathrm{C}$ for $30 \mathrm{~min}$ followed by removal of pentane and excess of oxalyl chloride under reduced pressure at $0^{\circ} \mathrm{C}$. After removal was 
complete, the flask was purged by dry argon and $35 \mathrm{ml}$ of cold dry diethyl ether was added. The resulting solution was immediately used in the next step. Phenoxyoxalyl tert-Butyl Peroxide.

To the solution of tert-Butylperoxyoxalyl Chloride obtained from the previous step the solution of phenol $(2.4 \mathrm{~g}, 25.6 \mathrm{mmol})$ and pyridine $(2.02 \mathrm{~g}, 25.6 \mathrm{mmol})$ in $15 \mathrm{ml}$ of dry diethyl ether was slowly added via syringe under atmosphere of dry $\operatorname{argon}$ at $0^{\circ} \mathrm{C}$. The reaction mixture was stirred for $30 \mathrm{~min}$ at $0^{\circ} \mathrm{C}$, then filtered and washed consequently with cold aqueous solutions of $10 \% \mathrm{H}_{2} \mathrm{SO}_{4}, 10 \% \mathrm{NaHCO}_{3}$, and water. The resulting ether solution was dried over $\mathrm{Na}_{2} \mathrm{SO}_{4}$. The diethyl ether was removed under reduced pressure at $0^{\circ} \mathrm{C}$, the residue was dissolved in pentane and filtered through $2 \mathrm{~cm}$ layer of silica. The pentane was removed under reduced pressure at $0^{\circ} \mathrm{C}$ to yield $1.3 \mathrm{~g}$ (21\%) of colorless oil. This product was free of phenol and contained only traces of ditert-Butylperoxalate. The compound is stable when stored in the dark at $-18^{\circ} \mathrm{C} .{ }^{1} \mathrm{H}$ NMR (300 MHz, $\mathrm{CDCl}_{3}$ ), $\delta$, ppm: 7.47-7.38 (m, 2H, 3-ArH + 5-ArH), 7.34-7.27 (m, 1H, 4$\mathrm{ArH}), 7.24-7.16(\mathrm{~m}, 2 \mathrm{H}, 2-\mathrm{ArH}+6-\mathrm{ArH}), 1.42\left(\mathrm{~s}, 9 \mathrm{H}, \mathrm{CH}_{3}\right) .{ }^{13} \mathrm{C}$ NMR $(75 \mathrm{MHz}$, $\mathrm{CDCl}_{3}$ ), $\delta$, ppm: 155.5 (1C, PhO-CO), 154.4 (1C, CO-OO), 149.7 (1C, Cl-Ar), 129.7 (2C, C3-Ar + C5-Ar), $127.0(1 \mathrm{C}, C 4-\mathrm{Ar}), 120.8$ (2C,C2-Ar + C6-Ar), $85.7(1 \mathrm{C}$, $\left.\mathrm{C}\left(\mathrm{CH}_{3}\right)_{3}\right), 26.0\left(3 \mathrm{C}, \mathrm{CH}_{3}\right)$.

\section{2,4,6-Trichlorophenoxyoxalyl tert-Butyl Peroxide.}

The synthesis and work-up were similar to those described above. The solution of 2,4,6-Trichlorophenol (4.74 g, $24 \mathrm{mmol})$ and pyridine (1.90 g, $24 \mathrm{mmol})$ in $15 \mathrm{ml}$ of dry diethyl ether was used in the synthesis. Yield of $2.5 \mathrm{~g}(30 \%)$ was obtained with m. p. of the resulted solid being $38-40^{\circ} \mathrm{C} .{ }^{1} \mathrm{H}$ NMR $\left(300 \mathrm{MHz}, \mathrm{CDCl}_{3}\right), \delta$, ppm: $7.42(\mathrm{~s}, 2 \mathrm{H}, 3-$ 
$\operatorname{Ar} H+5-\mathrm{Ar} H), 1.42\left(\mathrm{~s}, 9 \mathrm{H}, \mathrm{CH}_{3}\right) .{ }^{13} \mathrm{C} \mathrm{NMR}\left(75 \mathrm{MHz}, \mathrm{CDCl}_{3}\right), \delta$, ppm: $154.1(1 \mathrm{C}, \mathrm{PhO}-$

CO), 152.1 (1C, CO-OO), 141.6 (1C, Cl-Ar), 133.4 (1C, C4-Ar), 129.0 (2C, C2-Ar + C6-Ar), 128.9 (2C, $\mathrm{C} 3-\mathrm{Ar}+\mathrm{C} 5-\mathrm{Ar}), 86.0\left(1 \mathrm{C}, \mathrm{C}\left(\mathrm{CH}_{3}\right)_{3}\right), 26.0\left(3 \mathrm{C}, \mathrm{CH}_{3}\right)$.

Literature:

[1] Lahti, P. M.; Modarelli, D. A.; Rossitto, F. C.; Inceli, A. L.; Ichimura, A. S.;

Ivatury, S. // Aryl Oxalate Derivatives as Convenient Precursors for Generation of Aryloxyl Radicals // J. Org. Chem. 1996. 61(5), 1730-1738.

\section{Synthesis of NPPG}

The solution of benzoylformic acid (3.0 g, $20.0 \mathrm{mmol})$ and N,Ndimethylformamide ( $25 \mathrm{mg}$ - catalyst) in $30 \mathrm{ml}$ of dry dichloromethane was cooled to $0^{\circ} \mathrm{C}$ under atmosphere of dry argon. The oxalyl chloride $(3.99 \mathrm{~g}, 31.4 \mathrm{mmol})$ was added dropwise via syringe at stirring, the reaction mixture was stirred overnight. During this time the reaction mixture has reached the temperature of $25^{\circ} \mathrm{C}$. Dichloromethane and excess of oxalyl chloride were removed under reduced pressure at $25^{\circ} \mathrm{C}$, the flask was purged with dry argon, the residue was dissolved in $30 \mathrm{ml}$ of dry dichloromethane and dry pyridine $(0.47 \mathrm{~g}, 6 \mathrm{mmol})$ was added. The reaction mixture was cooled to $0^{\circ} \mathrm{C}$ under atmosphere of dry argon and a solution of 2,4-dinitrophenol (3.52 g, $19 \mathrm{mmol})$ and dry pyridine $(2.37 \mathrm{~g}, 30 \mathrm{mmol})$ in $30 \mathrm{ml}$ of dry dichloromethane was added via syringe. The reaction mixture was left overnight at stirring allowing the reaction mixture to reach the temperature of $25^{\circ} \mathrm{C}$. After that, the reaction mixture was washed consequently with cold solutions of $10 \% \mathrm{H}_{2} \mathrm{SO}_{4}$ (2 times), $5 \% \mathrm{NaHCO}_{3}$ (2 times), and water (1 time), dried over $\mathrm{Na}_{2} \mathrm{SO}_{4}$ and filtered through $2 \mathrm{~cm}$ layer of silica. Removing the solvent under reduced pressure gave yellow solid, which was found to be an 1:1 molar mixture of target ester 
and 2,4-dinitrophenol. The recrystallization from dichloromethane - hexane yielded $1.7 \mathrm{~g}$ (28\%) of pale-yellow crystals (m.p. $\left.128-129^{\circ} \mathrm{C}\right) .{ }^{1} \mathrm{H}$ NMR (300 MHz, $\mathrm{CDCl}_{3}$ ), $\delta$, ppm:

$9.06\left(\mathrm{~d}, J=2.7 \mathrm{~Hz}, 1 \mathrm{H}, 3-\mathrm{Ar}\left(\mathrm{NO}_{2}\right)_{2} H\right), 8.62\left(\mathrm{dd}, J_{1}=8.7 \mathrm{~Hz}, J_{2}=2.7 \mathrm{~Hz}, 1 \mathrm{H}, 5-\right.$

$\left.\operatorname{Ar}\left(\mathrm{NO}_{2}\right)_{2} H\right), 8.23-8.13(\mathrm{~m}, 2 \mathrm{H}, 2-\mathrm{Ar} H+6-\mathrm{ArH}), 7.79-7.71(\mathrm{~m}, 1 \mathrm{H}, 4-\mathrm{ArH}), 7.69(\mathrm{~d}$, $\left.J=8.7 \mathrm{~Hz}, 1 \mathrm{H}, 6-\operatorname{Ar}\left(\mathrm{NO}_{2}\right)_{2} H\right), 7.64-7.54(\mathrm{~m}, 2 \mathrm{H}, 3-\mathrm{Ar} H+5-\operatorname{Ar} H) .{ }^{13} \mathrm{C} \mathrm{NMR}(75 \mathrm{MHz}$,

$\left.\mathrm{CDCl}_{3}\right), \delta$, ppm: $182.5(1 \mathrm{C}, \mathrm{Ph}-\mathrm{CO}), 159.2(1 \mathrm{C}, \mathrm{CO}-\mathrm{O}), 147.7\left(1 \mathrm{C}, \mathrm{Cl}-\mathrm{Ar}\left(\mathrm{NO}_{2}\right)_{2}\right), 145.9$

(1C, C4-Ar( $\left.\left(\mathrm{NO}_{2}\right)_{2}\right), 141.6\left(1 \mathrm{C}, C 2-\mathrm{Ar}\left(\mathrm{NO}_{2}\right)_{2}\right), 135.9$ (1C, C4-Ar), 131.7 (1C, Cl-Ar),

$130.5(2 \mathrm{C}, C 2-\mathrm{Ar}+C 6-\mathrm{Ar}), 129.4\left(1 \mathrm{C}, C 5-\mathrm{Ar}\left(\mathrm{NO}_{2}\right)_{2}\right), 129.2(2 \mathrm{C}, C 3-\mathrm{Ar}+C 5-\mathrm{Ar}), 126.7$

(1C, C6- $\left.\mathrm{Ar}\left(\mathrm{NO}_{2}\right)_{2}\right), 122.0\left(1 \mathrm{C}, C 3-\operatorname{Ar}\left(\mathrm{NO}_{2}\right)_{2}\right)$.

\section{Purification of DNPO}

Purification has been done by extracting the sample with $\mathrm{CHCl} 3$ in Soxhlet apparatus for three days. Crystallization of the solution obtained gave the product having m.p. 191$193^{\circ} \mathrm{C}$ (lit.: $189-190^{\circ} \mathrm{C}$ ). 


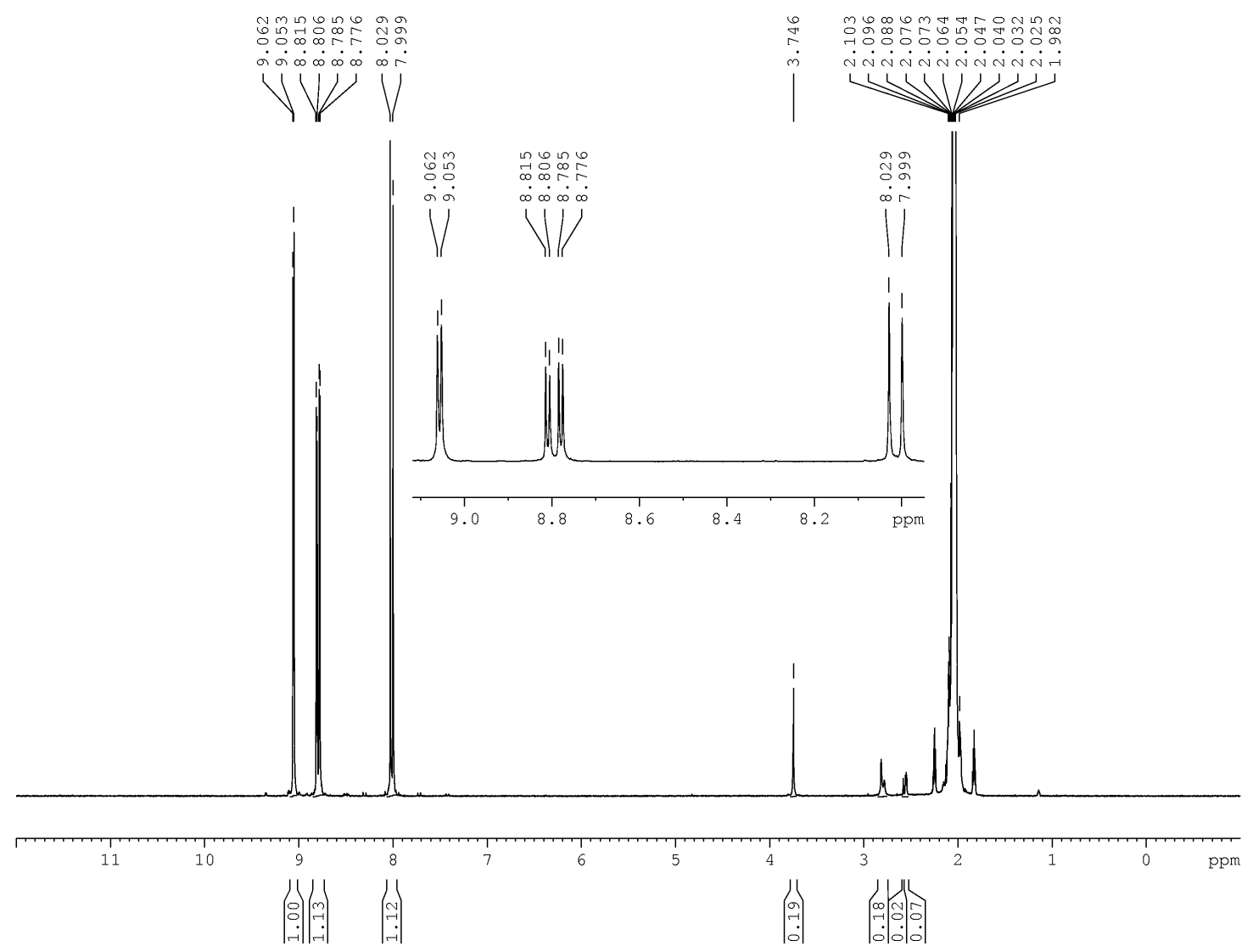

Figure S1. ${ }^{1} \mathrm{H}$ NMR of purified DNPO. 


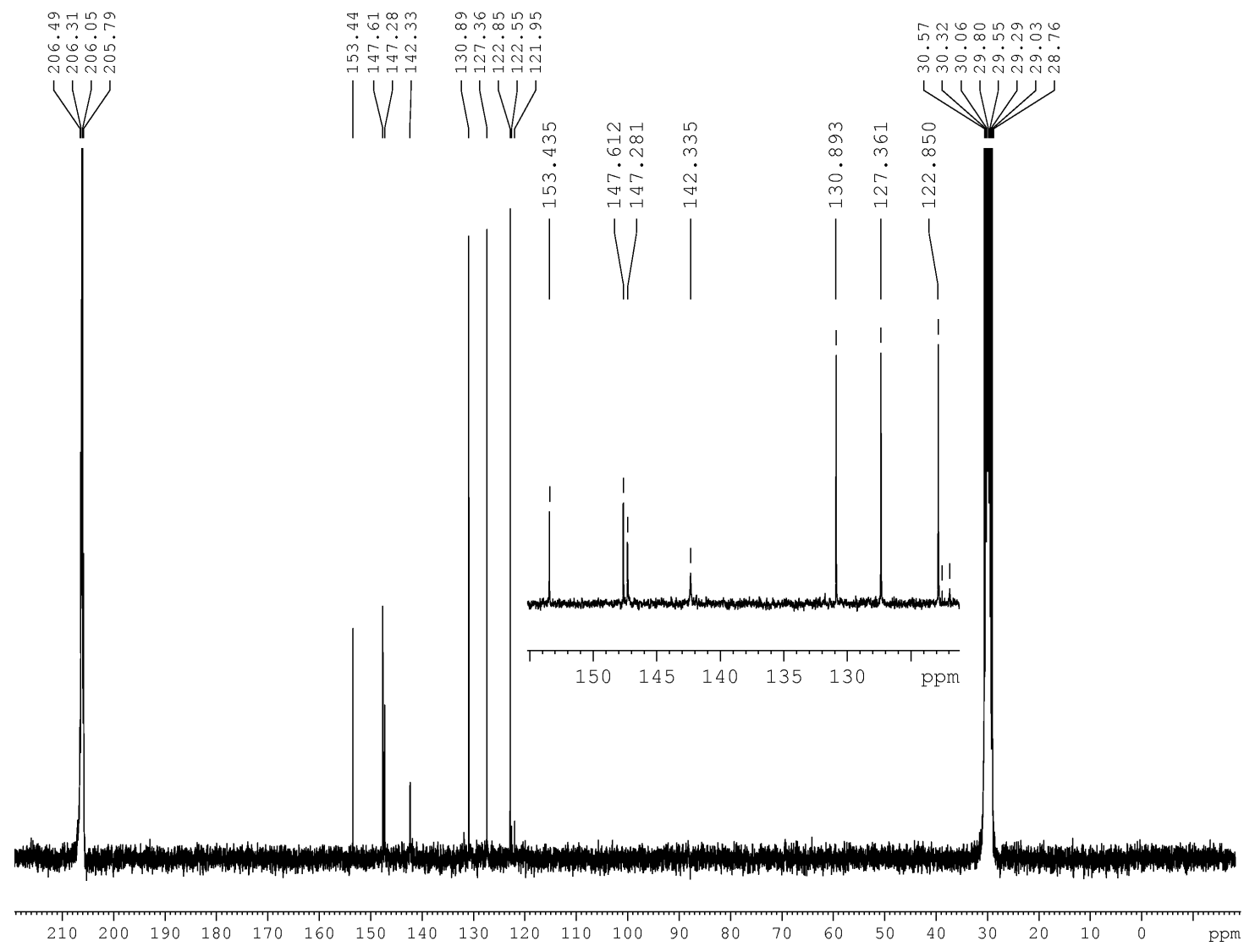

Figure S2. ${ }^{13} \mathrm{C}$ NMR of purified DNPO. 


\section{Additional Double Bond Conversion Curves}

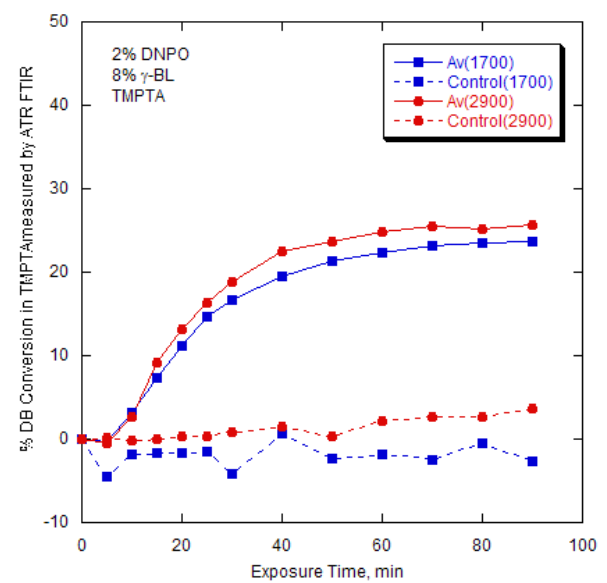

Figure S3. Comparison of DB conversion profiles for TMPTA obtained using carbonyl and $\mathrm{CH}$ stretch fundamentals.

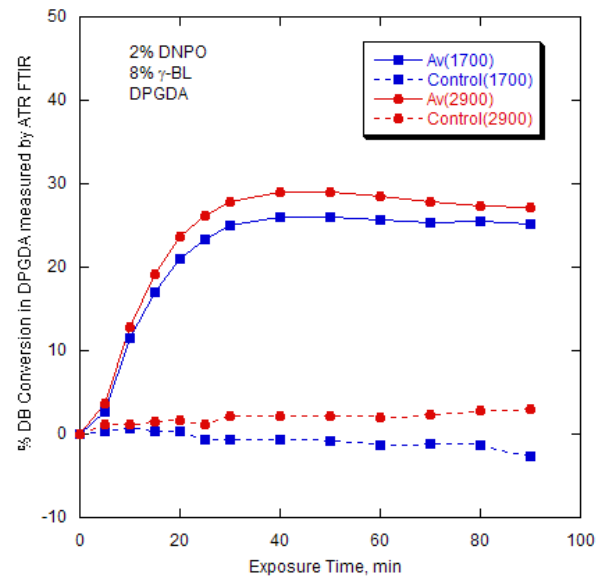

Figure S4. Comparison of DB conversion profiles for DPGDA obtained using carbonyl and $\mathrm{CH}$ stretch fundamentals. 


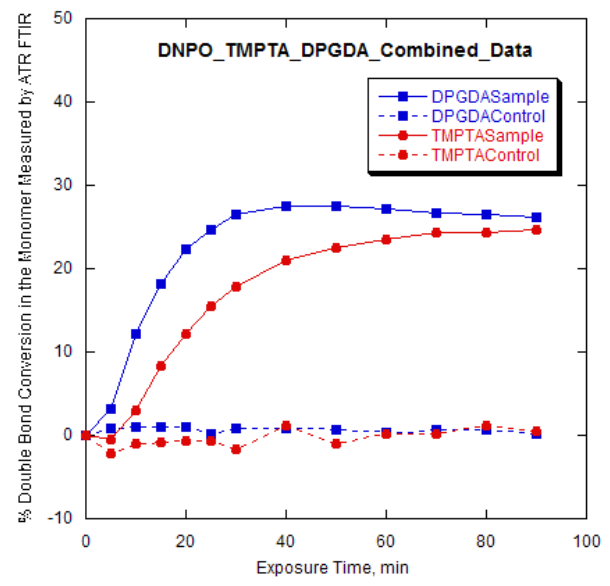

Figure S5. Combined data for TMPTA and DPGDA obtained by averaging data from $\mathrm{C}=\mathrm{O}$ and $\mathrm{CH}$ internal references.

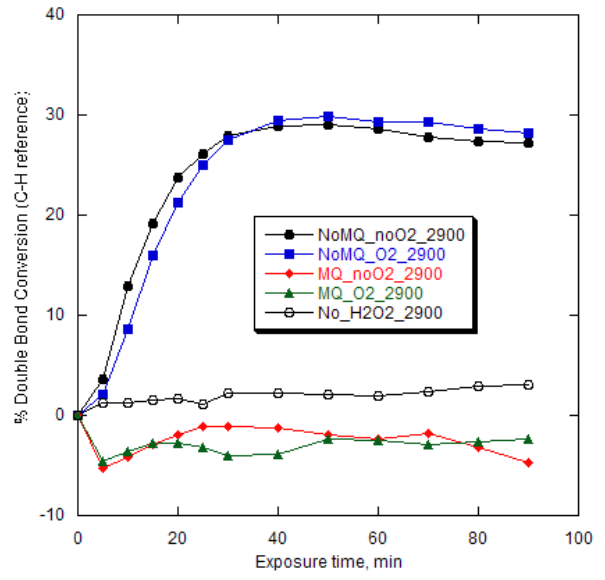

Figure S6. Control experiments investigating the effect of various factors on RC activity for $\mathrm{CH}$ internal reference. 


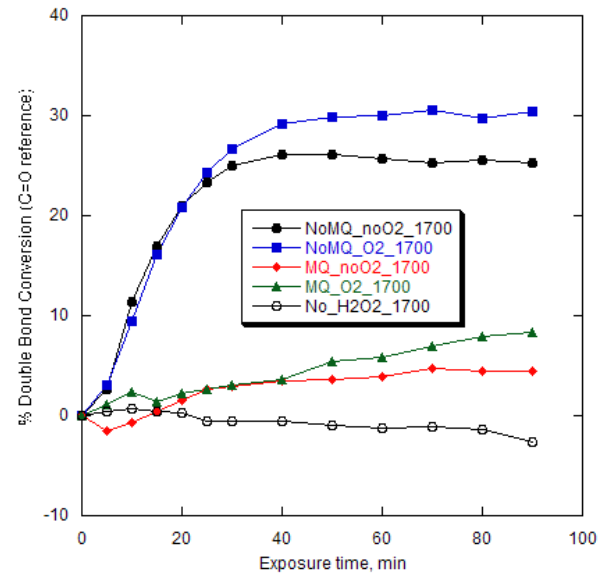

Figure S7. Control experiments investigating the effect of various factors on RC activity for $\mathrm{C}=\mathrm{O}$ internal reference. 


\section{LFP Studies}

$\underline{308 \mathrm{~nm} \text { excitation }}$
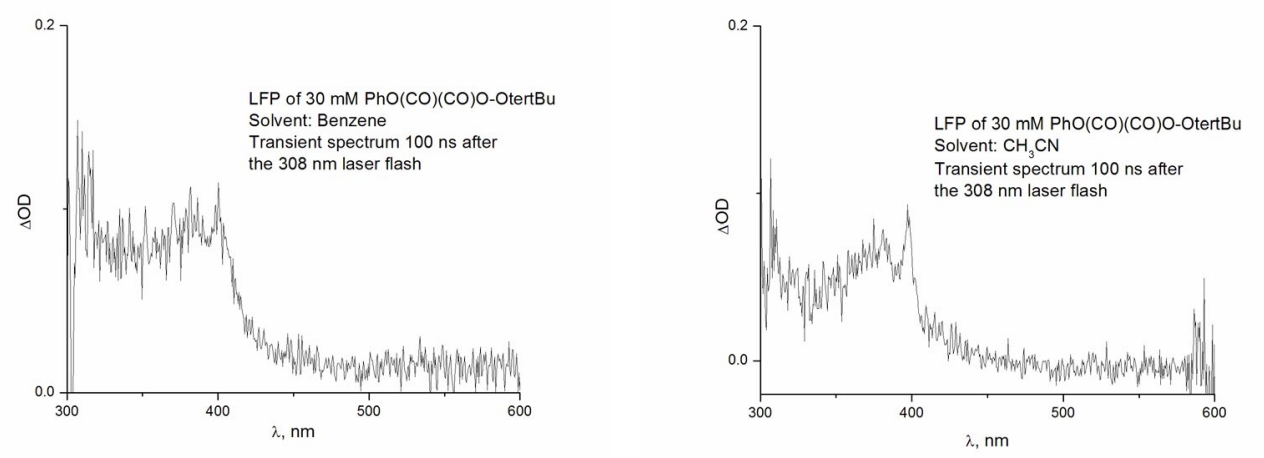

Figure S8. Transient spectra obtained $100 \mathrm{~ns}$ after $308 \mathrm{~nm}$ excimer laser excitation of 30 $\mathrm{mM}$ of Phenoxyoxalyl tert-Butyl Peroxide in benzene (left) and $\mathrm{CH}_{3} \mathrm{CN}$ (right). Two maxima characteristical of phenoxyl radical are observed in the $380-405 \mathrm{~nm}$ interval for both solvents.
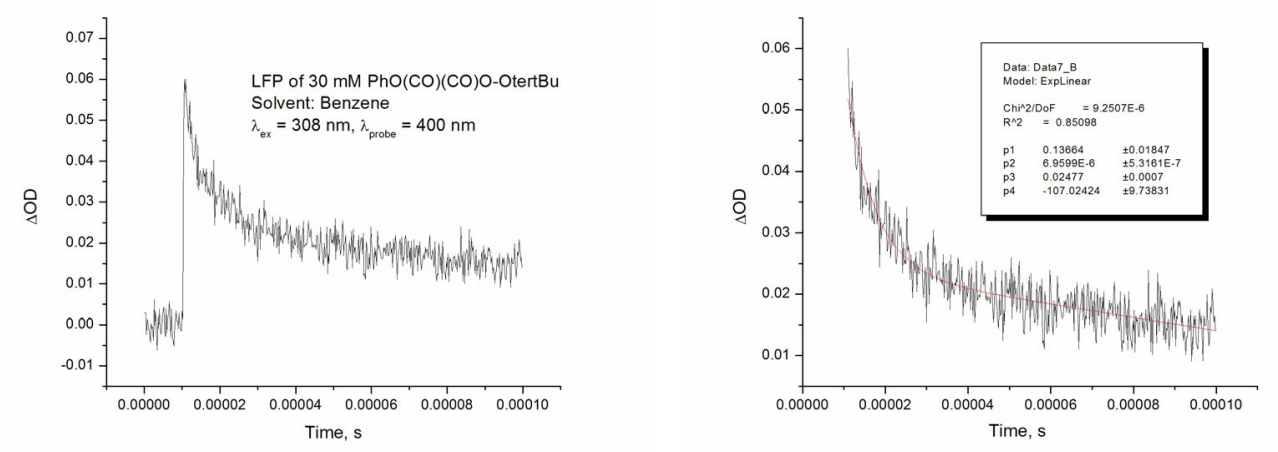

Figure S9. Kinetic trace and its fit obtained by monitoring decay of the $\mathrm{PhO} \bullet$ transient signal in benzene at $400 \mathrm{~nm}$. Lifetime of $7.0 \mu \mathrm{s}$ was obtained using (monoexponential + linear) fit.

The obtained lifetimes for this and other traces are used only to compare transient signals under different conditions and do not represent any kinetic information as $\mathrm{PhO} \bullet$ radicals decay via nonexponential pathway. 

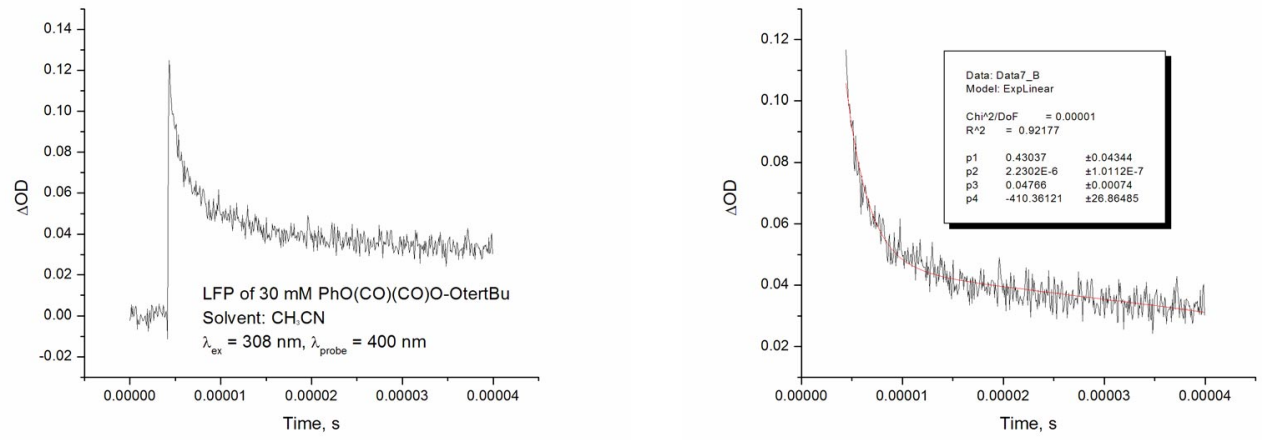

Figure $\mathrm{S} 10$. Kinetic trace and its fit obtained by monitoring decay of the $\mathrm{PhO} \bullet$ transient signal in acetonitrile at $400 \mathrm{~nm}$. Lifetime of $2.2 \mu$ s was obtained.
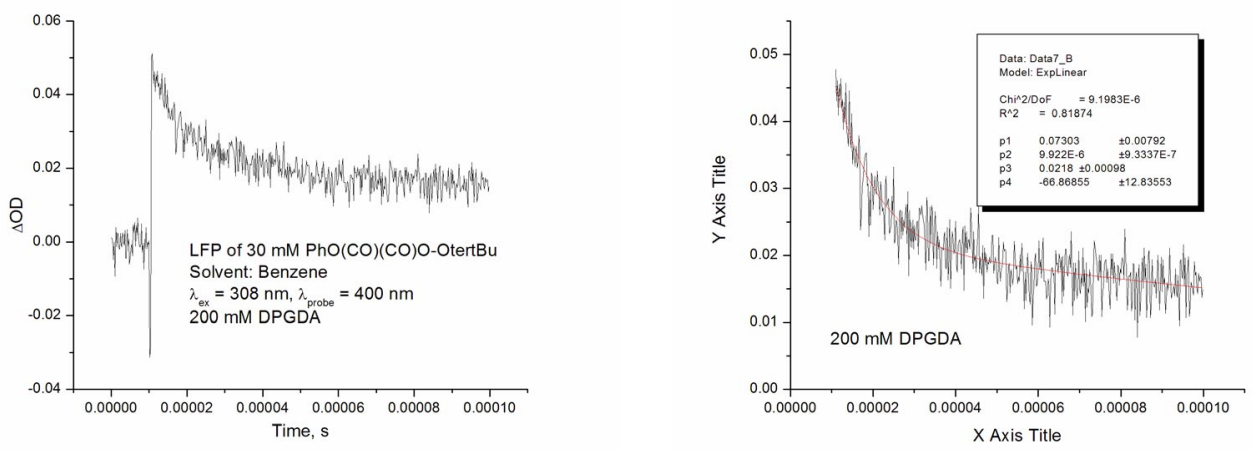

Figure S11. Kinetic trace and its fit obtained by monitoring decay of the $\mathrm{PhO} \bullet$ transient signal in benzene at $400 \mathrm{~nm}$ with $200 \mathrm{mM}$ of DPGDA monomer added. Lifetime of 9.9 $\mu$ s was obtained, which is not significantly different from $7.0 \mathrm{~ms}$ lifetime of $\mathrm{PhO} \bullet$ in the absence of any monomer. This indicates no reactivity between PhO• and DPGDA.
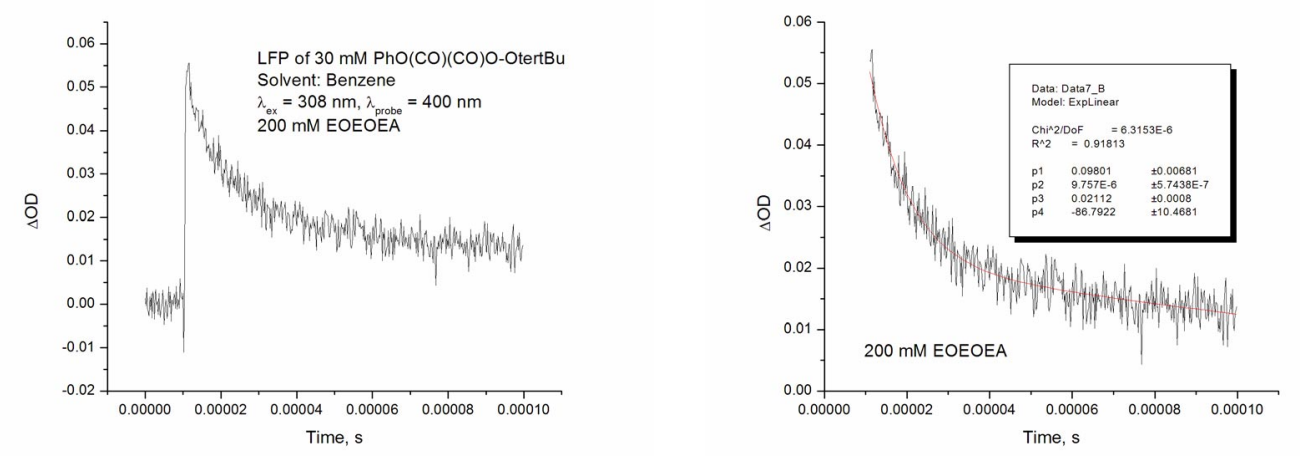

Figure S12. Kinetic trace and its fit obtained by monitoring decay of the $\mathrm{PhO} \bullet$ transient signal in benzene at $400 \mathrm{~nm}$ with $200 \mathrm{mM}$ of EOEOEA monomer added. Lifetime of 9.8 $\mu$ s was obtained, which is not significantly different from $7.0 \mathrm{~ms}$ lifetime of $\mathrm{PhO} \bullet$ in the absence of any monomer. This indicates no reactivity between $\mathrm{PhO} \bullet$ and EOEOEA. 

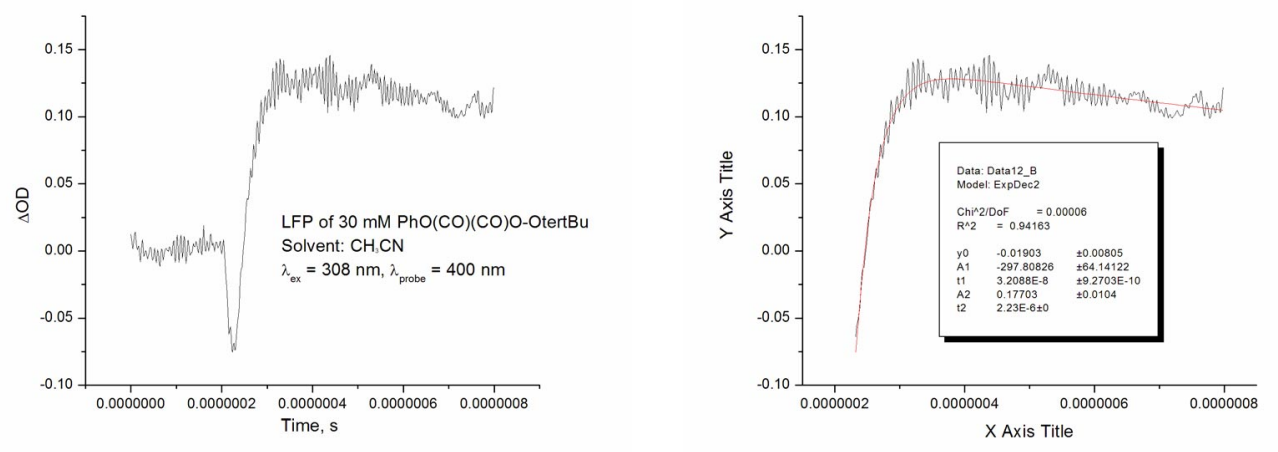

Figure S13. Kinetic trace and its fit obtained by monitoring the growth of the $\mathrm{PhO} \bullet$ transient signal in benzene at $400 \mathrm{~nm}$. Growth lifetime of $32 \mathrm{~ns}$ was obtained, which corresponds to the response time of the LFP setup. Therefore, the rate of $\mathrm{PhO} \bullet$ formation and, hence, the rate of $\mathrm{PhO}(\mathrm{CO}) \bullet$ decarbonylation is faster than the $32 \mathrm{~ns}$ response time of the LFP setup.

\section{$\underline{355 \mathrm{~nm} \text { excitation }}$}

$\mathrm{PhO} \bullet$ radicals were generated according to the procedure reported by Ingold and coworkers (JACS, 1994, 116(21), 9440 - 9447).

Solvent: $\left(\mathrm{Me}_{3} \mathrm{CO}\right)_{2} /$ benzene $3 / 1 ;[\mathrm{PhOH}]=1.4 \mathrm{M}$.

Mechanism of Formation:

$$
\begin{aligned}
& \mathrm{Me}_{3} \mathrm{COOCMe}_{3} \rightarrow 2 \mathrm{Me}_{3} \mathrm{CO} \bullet \\
& \mathrm{Me}_{3} \mathrm{CO}+\mathrm{PhOH} \rightarrow \mathrm{Me}_{3} \mathrm{COH}+\mathrm{PhO} \bullet
\end{aligned}
$$

Phenoxyl radicals are generated within the time interval of the laser flash (ca. $10 \mathrm{~ns}$ ) owing to fast time of reactions (1) and (2)

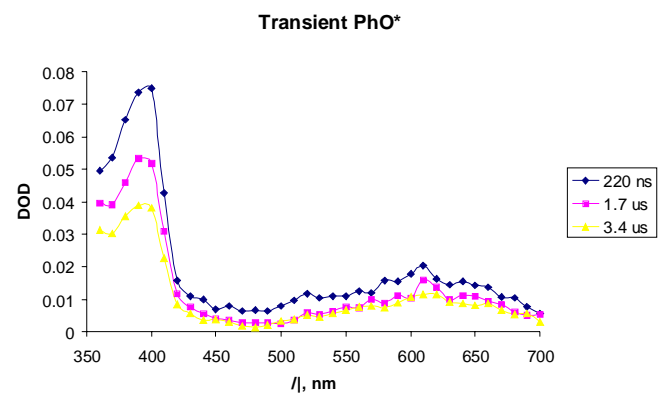

Figure S14. Transient spectra obtained 220, 1700 and $3400 \mathrm{~ns}$ after $355 \mathrm{~nm}$ Nd:Yag laser excitation of $1.4 \mathrm{M}$ phenol in $3 / 1\left(\mathrm{Me}_{3} \mathrm{CO}\right)_{2} /$ benzene. In addition to two characteristic maxima in the $380-405 \mathrm{~nm}$ interval, weaker maximum was observed around $610 \mathrm{~nm}$. 

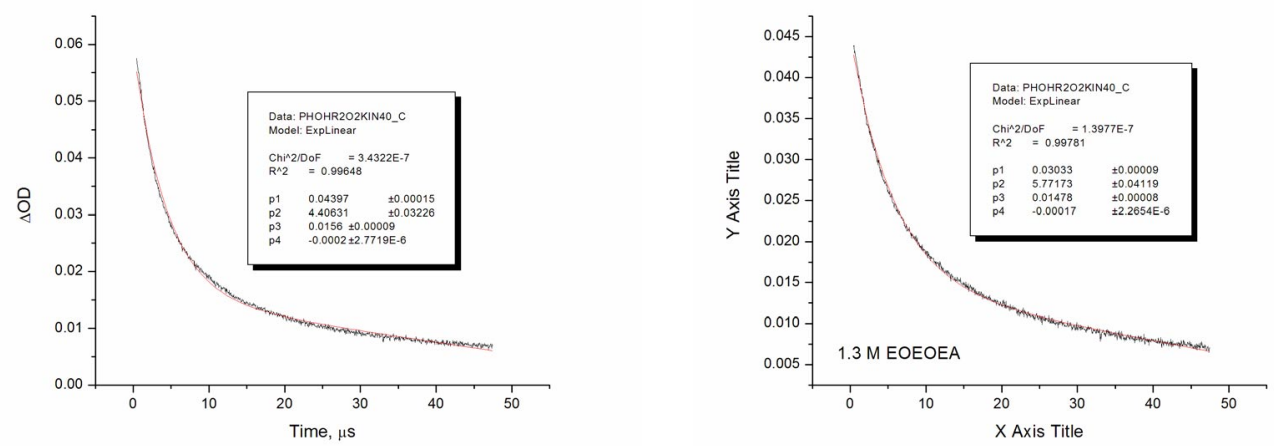

Figure S15. Fitted kinetic traces obtained by monitoring decay of the $\mathrm{PhO} \bullet$ transient signal in benzene at $400 \mathrm{~nm}$ without monomer (left) and with 1.3 M DPGDA monomer added (right). Lifetimes of 4.4 and $5.8 \mu \mathrm{s}$, respectively, were obtained using (monoexponential + linear) fit. This confirms no reactivity between PhO• and DPGDA.

\section{$\underline{266 \mathrm{~nm} \text { excitation }}$}

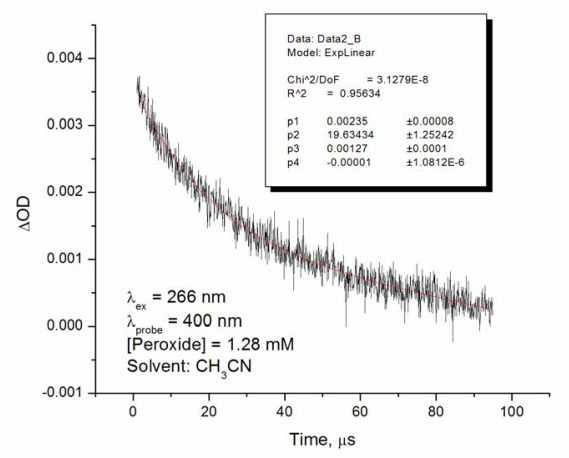

Figure S16. Fitted kinetic trace obtained by monitoring decay of the $\mathrm{PhO} \bullet$ transient signal in benzene at $400 \mathrm{~nm}$ after $266 \mathrm{~nm} \mathrm{Nd}$ :Yag laser excitation of $1.28 \mathrm{mM}$ of Phenoxyoxalyl tert-Butyl Peroxide.

$\tau_{\text {phenoxyl }}=19.6 \mu \mathrm{s}$

Addition up to $25 \mathrm{mM}$ of both DPGDA and EOEOEA did not result in significant change of the lifetime

Higher concentrations of monomer could not be used due to own absorbance of acrylates at $266 \mathrm{~nm}$. 